\title{
Article
}

\section{Type III TGF- $\beta$ Receptor Down-Regulation Promoted Tumor Progression via Complement Component C5a Induction in Hepatocellular Carcinoma}

\author{
Oscar Wai Ho Yeung, Xiang Qi, Li Pang, Hui Liu, Kevin Tak Pan Ng $\mathbb{1}$, Jiang Liu, Chung Mau Lo and Kwan Man * \\ Department of Surgery, HKU-SZH \& The University of Hong Kong, Pokfulam, Hong Kong SAR, China; \\ why21@hku.hk (O.W.H.Y.); Qixiang515@connect.hku.hk (X.Q.); leepang@connect.hku.hk (L.P.); \\ liuhui25@hku.hk (H.L.); ledodes@hku.hk (K.T.P.N.); u3003218@connect.hku.hk (J.L.); chungmlo@hku.hk (C.M.L.) \\ * Correspondence: kwanman@hku.hk; Tel.: +852-39179646
}

check for updates

Citation: Yeung, O.W.H.; Qi, X.; Pang, L.; Liu, H.; Ng, K.T.P.; Liu, J.; Lo, C.M.; Man, K. Type III TGF- $\beta$ Receptor Down-Regulation Promoted Tumor Progression via Complement Component $\mathrm{C} 5 \mathrm{a}$ Induction in Hepatocellular Carcinoma. Cancers 2021, 13, 1503. https://doi.org/ 10.3390/cancers 13071503

Received: 12 January 2021 Accepted: 26 January 2021 Published: 25 March 2021

Publisher's Note: MDPI stays neutral with regard to jurisdictional claims in published maps and institutional affiliations.

Copyright: (c) 2021 by the authors. Licensee MDPI, Basel, Switzerland. This article is an open access article distributed under the terms and conditions of the Creative Commons Attribution (CC BY) license (https:/ / creativecommons.org/licenses/by/ $4.0 /)$.
Simple Summary: The clinical implications of TGF $\beta$ R3 downregulation are currently unknown in hepatocellular carcinoma (HCC). Clinically, we identified that HCC patients with low expression levels of tumoral TGF $\beta$ R3 exhibited significantly late tumor stages and shortened survival outcomes. Moreover, HCC patients developed lower plasma levels of TGF $\beta$ R3 (sTGF $\beta$ R3) $(8.9 \mathrm{ng} / \mathrm{mL}) \mathrm{com}$ pared to healthy individuals $(15.9 \mathrm{ng} / \mathrm{mL})$, which represented a potential diagnostic marker. Similar to tumoral TGF $\beta$ R3, low levels of plasma sTGF $\beta$ R3 are also associated with poor clinical outcomes in HCC. To determine its tumor-suppressing capacities, continuous injection of sTGF $\beta$ R3 in an orthotopic liver tumor model was performed, resulting in 2-fold tumor volume reduction compared to control. Decreased expression of TGF $\beta$ R3 induced the upregulation of tumoral complement component $\mathrm{C} 5 \mathrm{a}$ in HCC, which was found to contribute to poor clinical outcomes and promote tumor progression via a novel function in activating the tumor-promoting macrophages.

Abstract: Background and Aims-Transforming growth factor-beta (TGF- $\beta$ ) signaling orchestrates tumorigenesis and one of the family members, TGF- $\beta$ receptor type III (TGF $\beta$ R3), are distinctively under-expressed in numerous malignancies. Currently, the clinical impact of TGF $\beta$ R3 downregulation and the underlying mechanism remains unclear in hepatocellular carcinoma (HCC). Here, we aimed to identify the tumor-promoting roles of decreased TGF $\beta$ R3 expression in HCC progression. Materials and Methods-For clinical analysis, plasma and liver specimens were collected from 100 HCC patients who underwent curative resection for the quantification of TGF $\beta$ R3 by q-PCR and ELISA. To study the tumor-promoting mechanism of TGF $\beta$ R3 downregulation, HCC mouse models and TGF $\beta$ R3 knockout cell lines were applied. Results-Significant downregulation of TGF $\beta$ R3 and its soluble form (sTGF $\beta$ R3) were found in HCC tissues and plasma compared to healthy individuals $(p<0.01)$. Patients with $<9.4 \mathrm{ng} / \mathrm{mL}$ sTGF $\beta$ R3 exhibited advanced tumor stage, higher recurrence rate and shorter disease-free survival $(p<0.05)$. The tumor-suppressive function of sTGF $\beta$ R3 was further revealed in an orthotopic mouse HCC model, resulting in 2-fold tumor volume reduction. In TGF $\beta$ R3 knockout hepatocyte and HCC cells, increased complement component C5a was observed and strongly correlated with shorter survival and advanced tumor stage $(p<0.01)$. Interestingly, $\mathrm{C} 5 \mathrm{a}$ activated the tumor-promoting Th-17 response in tumor associated macrophages. Conclusion-TGF $\beta$ R3 suppressed tumor progression, and decreased expression resulted in poor prognosis in HCC patients through upregulation of tumor-promoting complement C5a.

Keywords: clinical outcomes; tumor-suppressive protein; diagnosis prediction; therapeutic potential; complement component

\section{Introduction}

The multifunctional cytokine transforming growth factor- $\beta$ (TGF $\beta$ ) is a key regulator in multiple cellular processes including proliferation, differentiation, migration and 
immunological responses [1]. Unlike the other well-defined signaling pathways, whether TGF- $\beta$ exhibits tumor-suppression or tumor-promoting functions remains controversial. Among the members of the super-family, type III receptor of TGF- $\beta$ (TGF $\beta$ R3) has shown a distinctive role in tumor biology. TGF $\beta$ R3 is a co-receptor presenting TGF- $\beta$ ligands to the TGF $\beta$ R1 and ubiquitously expressed on nearly all cell types. It plays an essential role in mediating cell proliferation, apoptosis, differentiation, and migration in most human tissues [2]. Loss or reduced expression of TGF $\beta$ R3 have been reported in many malignancies including breast, kidney, lung, ovaries, prostate and liver [3]. It has also been shown to be a key suppressor of tumor cell invasion, proliferation and angiogenesis in both in vitro and in vivo cancer models [3]. Apart from a transmembrane protein found in the cell membranes, the receptor can undergo ectodomain shedding from the cell surface to form soluble TGF $\beta$ R3 (sTGF $\beta$ R3) and be released to extracellular matrix and circulation. Studies have demonstrated its anti-tumor capacities in melanoma and breast cancer by sequestering TGF- $\beta$ ligands for downstream pro-tumor signaling [4-6]. To date, little is known about the clinical implications and molecular mechanisms of TGF $\beta$ R3 in hepatocellular carcinoma (HCC).

HCC has a very high metastatic and fatality rate (overall mortality to incidence ratio $>90 \%$ ), representing the second most common cause of death from cancer worldwide. Curative treatment options, including surgical and radiofrequency ablation, can be only applied to the patients with limited tumor burden [7]. Previously, we reported the clinical significances of alternative activated macrophages in promoting poor prognosis and tumor invasiveness in the disease [8]. In contrast, the recruitment and activating mechanisms of such an immune population by HCC remain elusive. TGF $\beta$ R3 has been shown to possess the capacity to promote tumor-suppressing immunity [9]. Together with the observation that $66 \%$ patients showed decreased expression of the receptor, we investigated the clinical impact of TGF $\beta$ R3 downregulation and its immuno-regulatory mechanism in HCC. In the present study, we revealed that the loss of TGF $\beta$ R3 contributed to poor prognosis and promoted tumor progression via the upregulation of complement component C5a.

\section{Results}

\subsection{Aberrant Down-Regulation of TGF $\beta$ R3 Expression in HCC Patients}

The clinical characteristics of the 100 patients who underwent curative resection were described in Table S1. To determine the protein and gene expression level of tumoral TGF $\beta$ R3, immunohistochemistry, Western blotting and quantitative-PCR were applied. Downregulation of TGF $\beta$ R3 in tumor was consistently observed in both immuno-staining and blotting studies (Figure $1 \mathrm{~A}-\mathrm{C}$ ). Further transcript analysis revealed a significant 1.43and 0.89 -fold decrease in TGF $\beta$ R3 in HCC tumor compared to adjacent non-tumoral and normal tissues, respectively (Figure 1D). Such downregulation was observed in $66 \%$ of the studied HCC population, as well as in seven HCC-patient-derived cell-lines (Figure 1E). All the data collectively illustrated the significant reduction in TGF $\beta R 3$ at both transcript and protein levels in HCC patients. Such down-regulation was also validated in publicly available datasets from Oncomine (www.oncomine.org) and TCGA/GTEx by using GEPIA (http://gepia.cancer-pku.cn/) (Figure S1). 

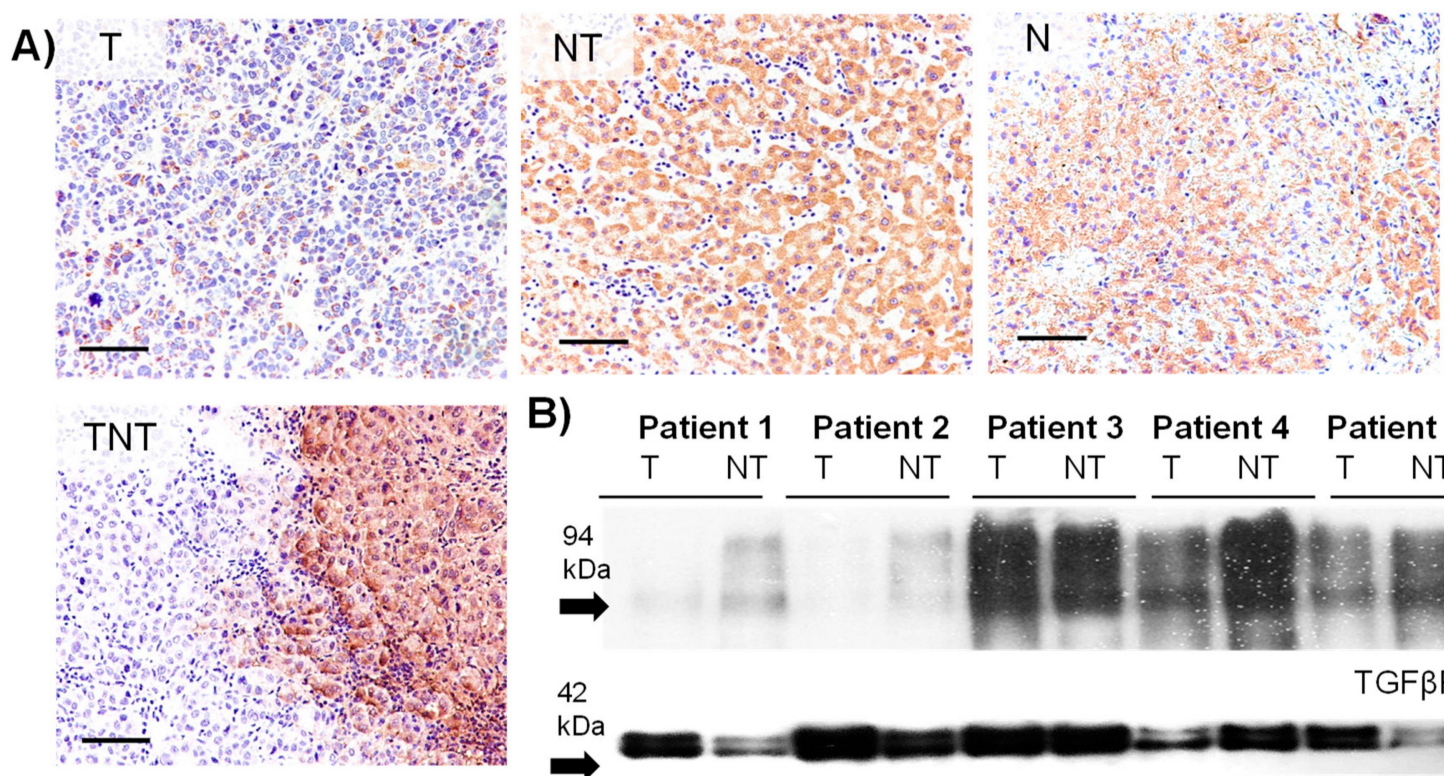

\section{B) Patient 1 Patient 2 Patient 3 Patient 4 Patient 5}

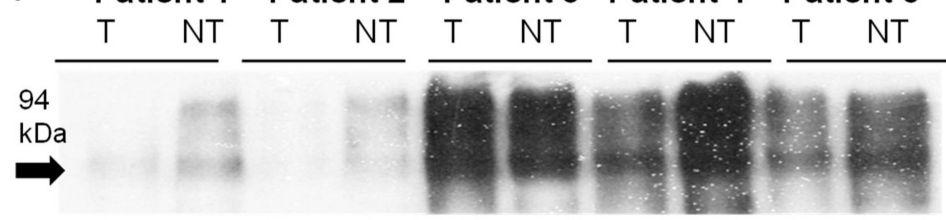

42

TGF $\beta R 3$
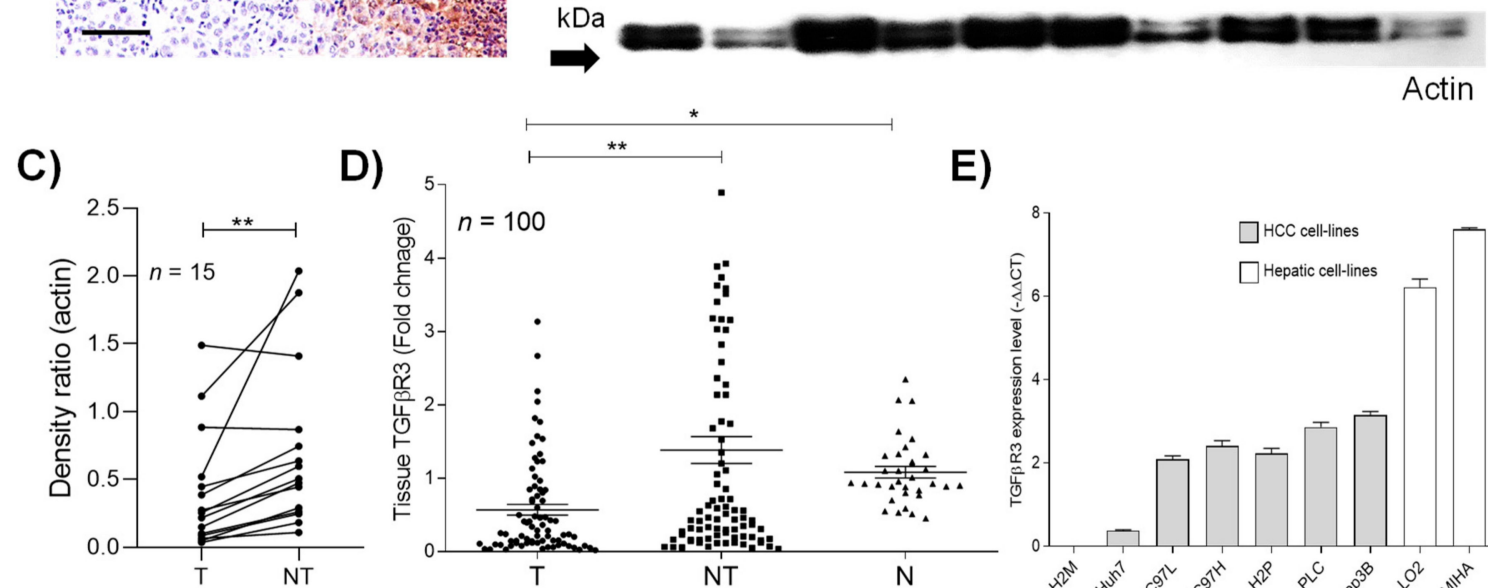

D)

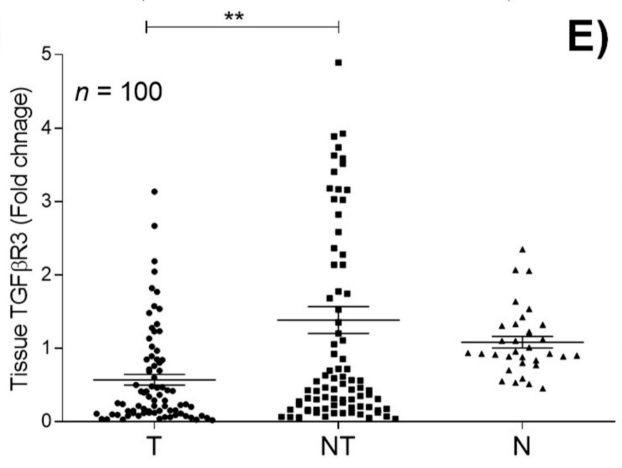

E)

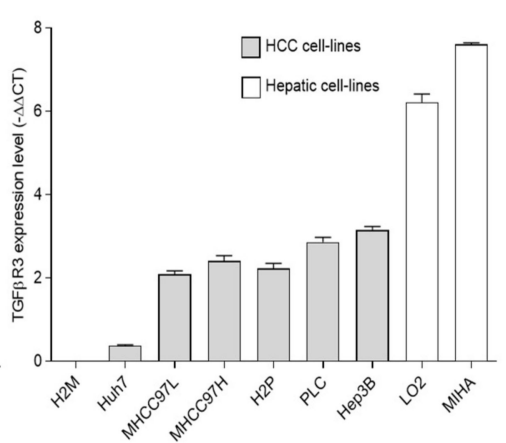

F)

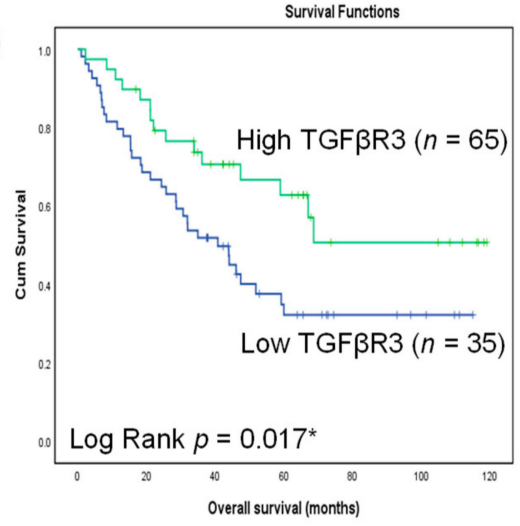

G)

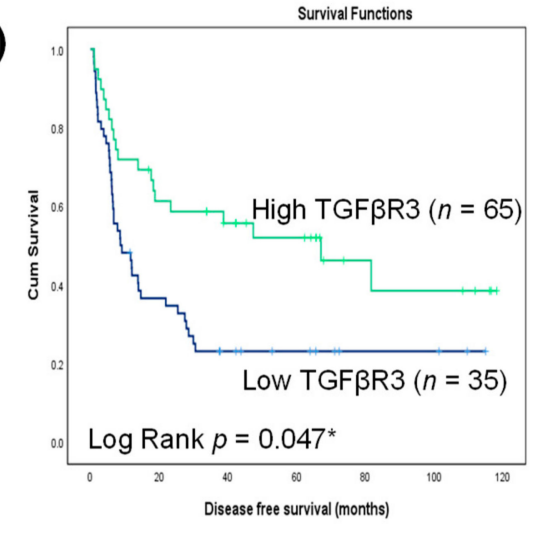

Figure 1. Clinical characteristics of transforming growth factor beta type III receptor (TGF $\beta$ R3) in hepatocellular carcinoma (HCC) tumoral tissue. (A) Representative image of immunohistochemical staining of TGF $\beta$ R3. (B) Western blotting analysis of the protein level of TGF $\beta$ R3. (C) Densitometric quantification of Western blotting relative to actin. (D) Quantitative-PCR analysis of transcript level of TGF $\beta$ R3. (E) Transcript analysis of TGF $\beta$ R3 in hepatocyte and HCC cell-lines. Kaplan-Meier analysis of $(\mathbf{F})$ overall survival and $(\mathbf{G})$ disease-free survival in HCC patients associated with the expression level of tumoral TGF $\beta$ R3 transcript. T: tumor, NT: tumor-adjacent non-tumor, N: normal liver, TNT: intra- and peri-tumor; Scale bar: $50 \mu \mathrm{m}$; ${ }^{*} p<0.05,{ }^{* *} p<0.01$. Error bar indicated SEM. (Unpaired $t$-test for Figure 1C,D) (Paired $t$-test for Figure 1E) (Log rank test for Figure 1F,G). 


\subsection{Down-Regulation of TGF $\beta$ R Correlated with Poor Prognosis in HCC Patients}

When analyzed by the Kaplan-Meier method with log-rank statistics, low levels of tumoral TGF $\beta$ R3 transcript were found to be associated with poor overall survival $(p=0.017)$ and disease-free survival $(p=0.047)$ (Figure 1F,G). Similar clinical traits of TGF $\beta$ R3 were also confirmed in the publicly available datasets from GEPIA (Figure S2). Apart from survival outcomes, the correlation between clinicopathological characteristics and TGF $\beta$ R3 expression was examined. As summarized (Table 1), high levels of alphafetoprotein (AFP) $(>20 \mathrm{ng} / \mathrm{mL})(p=0.014)$, and advanced tumor stage in all grading systems, including UICC $(p=0.01)$, Edmonson $(p=0.003)$ and AJCC $(p=0.048)$, were found to be associated with low expression of TGF $\beta$ R3. These findings highlighted the clinical significance of TGF $\beta$ R3 in prognosis as well as tumor progression in HCC patients.

Table 1. Correlation between TGF $\beta$ R3 and clinicopathologic parameters.

\begin{tabular}{|c|c|c|c|}
\hline \multicolumn{4}{|c|}{$\begin{array}{l}\text { TGF } \beta \text { R3 Expression in Tumor with Respect } \\
\text { to Adjacent Non-Tumor Tissue }(n=100)\end{array}$} \\
\hline Clinical Parameter & Fold Change $\leq 2$ & Fold Change $>2$ & $p$ Value \\
\hline \multicolumn{4}{|l|}{ Gender (n) } \\
\hline Male & 50 & 29 & \multirow[t]{2}{*}{0.794} \\
\hline Female & 14 & 7 & \\
\hline \multicolumn{4}{|l|}{ Age (years) \# } \\
\hline$\leq 60$ & 35 & 16 & \multirow[t]{2}{*}{0.1} \\
\hline$>60$ & 25 & 24 & \\
\hline \multicolumn{4}{|l|}{ Hepatitis B carrier } \\
\hline Positive & 43 & 25 & \multirow{2}{*}{1.0} \\
\hline Negative & 20 & 12 & \\
\hline \multicolumn{4}{|l|}{$\mathrm{AFP}(\mathrm{ng} / \mathrm{mL})$} \\
\hline Abnormal (>20) & 45 & 17 & \multirow{2}{*}{$0.014^{*-1}$} \\
\hline Normal $(<20)$ & 17 & 21 & \\
\hline \multirow{2}{*}{\multicolumn{4}{|c|}{$\begin{array}{c}\text { Aspartate transaminase } \\
(\mathrm{U} / \mathrm{L})\end{array}$}} \\
\hline & & & \multirow{3}{*}{0.33} \\
\hline Abnormal $(>40)$ & 41 & $\begin{array}{l}21 \\
17\end{array}$ & \\
\hline Normal $(\leq 40)$ & 21 & 17 & \\
\hline \multicolumn{4}{|l|}{ Venous infiltration } \\
\hline Present & 40 & 16 & \multirow[t]{2}{*}{0.086} \\
\hline Absent & 24 & 20 & \\
\hline \multicolumn{4}{|l|}{ Size of tumor $(\mathrm{cm})$} \\
\hline Large $(>5)$ & 38 & 18 & \multirow[t]{2}{*}{0.239} \\
\hline Small $(\leq 5)$ & 24 & 20 & \\
\hline \multicolumn{4}{|l|}{ No. of nodules (n) } \\
\hline Multiple $(>1)$ & 22 & 15 & \multirow[t]{2}{*}{0.806} \\
\hline Single (1) & 40 & 23 & \\
\hline \multicolumn{4}{|l|}{ UICC grade } \\
\hline Early stage $(1,2)$ & 19 & 16 & \multirow[t]{2}{*}{$0.010^{* * \wedge}$} \\
\hline Late stage $(3,4)$ & 19 & 46 & \\
\hline \multicolumn{4}{|l|}{$\begin{array}{l}\text { Edmonson grade } \\
\text { (differentiated) }\end{array}$} \\
\hline Well & 9 & 6 & \multirow{3}{*}{$0.003^{* * \wedge}$} \\
\hline Moderately & 32 & 25 & \\
\hline Poorly & 23 & 5 & \\
\hline
\end{tabular}


Table 1. Cont.

\begin{tabular}{|c|c|c|c|}
\hline \multirow[b]{2}{*}{ Clinical Parameter } & \multicolumn{2}{|c|}{$\begin{array}{l}\text { TGF } \beta \text { R3 Expression in Tumor with Respect } \\
\text { to Adjacent Non-Tumor Tissue }(n=100)\end{array}$} & \multirow[b]{2}{*}{$p$ Value } \\
\hline & Fold Change $\leq 2$ & Fold Change $>2$ & \\
\hline \multicolumn{4}{|l|}{ AJCC grade (stage) } \\
\hline I & 15 & 19 & \multirow{3}{*}{$0.048^{* \wedge}$} \\
\hline II & 23 & 12 & \\
\hline IIIA & 20 & 11 & \\
\hline \multicolumn{3}{|l|}{$\begin{array}{l}\text { Ex- and intra hepatic } \\
\text { recurrence }\end{array}$} & \multirow{3}{*}{0.48} \\
\hline Present & 37 & 19 & \\
\hline Absent & 25 & 19 & \\
\hline
\end{tabular}
age of TGF $\beta$ R3 expression was 57.5 for fold change $\leq 2$ group and 56 for fold change $>2$.

\subsection{Soluble TGF $\beta R 3$ (sTGF $\beta R 3$ ) Exhibited Diagnostic and Prognostic Potentials in HCC}

As mentioned, TGF $\beta$ R3 undergoes ectodomain shedding released from tissue to extracellular matrix and circulation as soluble TGF $\beta$ R3 (sTGF $\beta$ R3). Compared to healthy individuals $(15.4 \mathrm{ng} / \mathrm{mL})$, a significant reduction in plasma sTGF $\beta$ R3 was observed in $72 \%$ of HCC patients $(8.9 \mathrm{ng} / \mathrm{mL})(p<0.01)$ (Figure $2 \mathrm{~A})$. Receiver-operating characteristics (ROC) curve analysis revealed that STGF $\beta$ R3 served as a biomarker for differentiating patients with HCC from healthy patients with an AUC of 0.838 (95\% CI, 0.78 to 0.90$)$ $(p<0.001)$ (Figure 2B). At the cut-off value of $9.4 \mathrm{ng} / \mathrm{mL}$ sTGF $\beta$ R3 in plasma, the sensitivity was $82.7 \%$ and the specificity was $77.4 \%$, respectively. With the acquired threshold value, Kaplan-Meier analysis revealed that patients with less than $9.4 \mathrm{ng} / \mathrm{mL}$ significantly developed poorer overall and disease-free survival compared to the $\geq 9.4 \mathrm{ng} / \mathrm{mL}$ group (Figure $2 \mathrm{C}, \mathrm{D}$, respectively) $(p<0.05)$. In terms of clinicopathological characteristics, a continuous decrease in plasma sTGF $\beta$ R3 was observed in patients with advanced tumor stages (Stage I and II: $14.99 \mathrm{ng} / \mathrm{mL} \pm 3.62$; Stage III: $7.67 \mathrm{ng} / \mathrm{mL} \pm 0.71$; Stage IV: $5.64 \mathrm{ng} / \mathrm{mL} \pm 0.42$ ) (Figure 2E). Low levels of plasma sTGF $\beta R 3$ were also associated with high levels of bilirubin $(>20 \mu \mathrm{mol} / \mathrm{l})(p<0.01)$, large tumor size $(>5 \mathrm{~cm})(p=0.012)$ and advanced tumor stages UICC $(p<0.01)$ and AJCC $(p=0.017)$ (Table 2$)$. Based on the finding that plasma sTGF $\beta$ R3 exhibited similar clinical associations with tumoral TGF $\beta$ R3, we further confirmed their strong correlation in HCC patients $\left(R^{2}=0.112, p<0.01\right)$ (Figure 2F).

Table 2. Correlation between plasma sTGF $\beta$ R3 and clinicopathologic parameters.

\begin{tabular}{|c|c|c|c|}
\hline \multicolumn{4}{|c|}{ Plasma sTGF $\beta$ R3 in HCC Patients $(n=100)$} \\
\hline Clinical Parameter & $\leq 9.4 \mathrm{ng} / \mathrm{ml}$ & $>9.4 \mathrm{ng} / \mathrm{ml}$ & $p$ Value \\
\hline \multicolumn{4}{|l|}{ Gender (n) } \\
\hline Male & 61 & 20 & 0.554 \\
\hline Female & 15 & 3 & \\
\hline \multicolumn{4}{|l|}{ Age (years) } \\
\hline$\leq 60$ & 44 & 15 & 0.631 \\
\hline$>60$ & 32 & 8 & \\
\hline \multicolumn{4}{|l|}{ Hepatitis B carrier } \\
\hline Positive & 66 & 21 & 0.447 \\
\hline Negative & 10 & 1 & \\
\hline \multicolumn{4}{|l|}{$\mathrm{AFP}(\mathrm{ng} / \mathrm{mL})$} \\
\hline Abnormal $(>20)$ & 46 & 9 & 0.141 \\
\hline Normal $(<20)$ & 29 & 13 & \\
\hline
\end{tabular}


Table 2. Cont.

\begin{tabular}{|c|c|c|c|}
\hline \multicolumn{4}{|c|}{ Plasma sTGF $\beta$ R3 in HCC Patients $(n=100)$} \\
\hline Clinical Parameter & $\leq 9.4 \mathrm{ng} / \mathrm{ml}$ & $>9.4 \mathrm{ng} / \mathrm{ml}$ & $p$ Value \\
\hline \multicolumn{4}{|l|}{ Bilirubin level $(\mu \mathrm{mol} / \mathrm{l})$} \\
\hline Abnormal $(>20)$ & 11 & 14 & $<0.001^{* *}$ \\
\hline Normal $(\leq 20)$ & 65 & 9 & \\
\hline \multicolumn{4}{|l|}{$\begin{array}{l}\text { Aspartate transaminase } \\
\qquad(\mathrm{U} / \mathrm{L})\end{array}$} \\
\hline Abnormal $(>40)$ & 52 & 20 & 0.11 \\
\hline Normal $(\leq 40)$ & 24 & 3 & \\
\hline \multicolumn{4}{|l|}{$\begin{array}{c}\text { Alanine transaminase } \\
\qquad(\mathrm{U} / \mathrm{L})\end{array}$} \\
\hline $\begin{array}{c}(\mathrm{U} / \mathrm{L}) \\
\text { Abnormal }(>45)\end{array}$ & 46 & 13 & 0.81 \\
\hline Normal $(\leq 45)$ & 30 & 10 & \\
\hline \multicolumn{4}{|l|}{ Size of tumor $(\mathrm{cm})$} \\
\hline Large $(>5)$ & 55 & 10 & $0.012^{* \wedge}$ \\
\hline Small $(\leq 5)$ & 20 & 13 & \\
\hline \multicolumn{4}{|l|}{ No of nodules (n) } \\
\hline Multiple (>1) & 32 & 7 & 0.335 \\
\hline Single (1) & 42 & 16 & \\
\hline \multicolumn{4}{|l|}{ UICC grade } \\
\hline Early stage $(1,2)$ & 12 & 11 & $0.004^{* * \wedge}$ \\
\hline Late stage $(3,4)$ & 63 & 12 & \\
\hline \multicolumn{4}{|l|}{ AJCC grade (stage) } \\
\hline I & 11 & 8 & \\
\hline II & 32 & 6 & $0.017^{* \wedge}$ \\
\hline IIIA & 24 & 3 & \\
\hline \multicolumn{4}{|l|}{$\begin{array}{l}\text { Ex- and in-tra hepatic } \\
\text { recurrence }\end{array}$} \\
\hline Present & 46 & 12 & 0.481 \\
\hline Absent & 30 & 11 & \\
\hline
\end{tabular}


A)

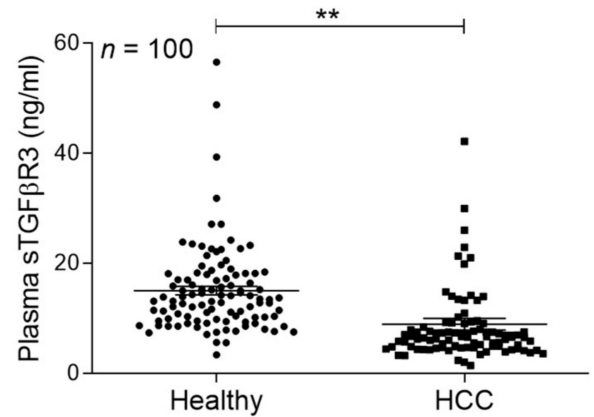

C)

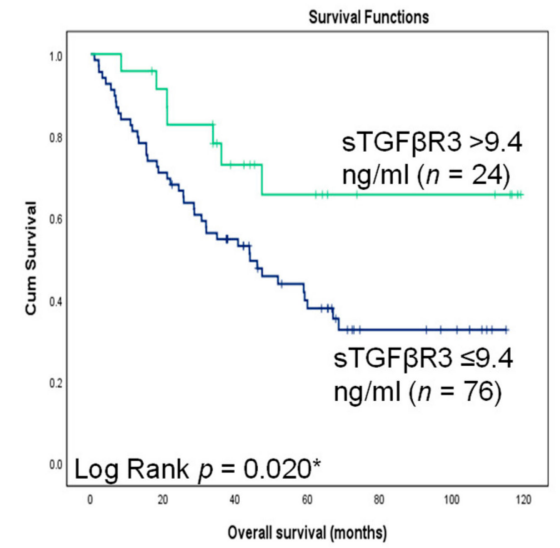

E)

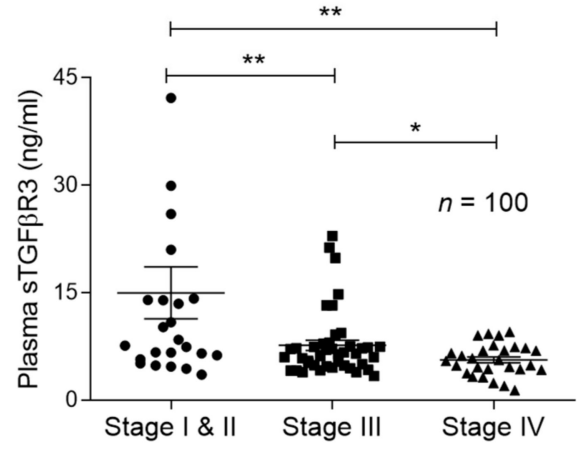

B)

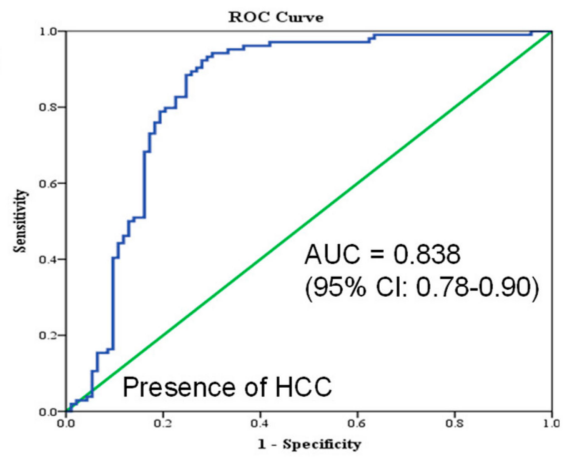

D)

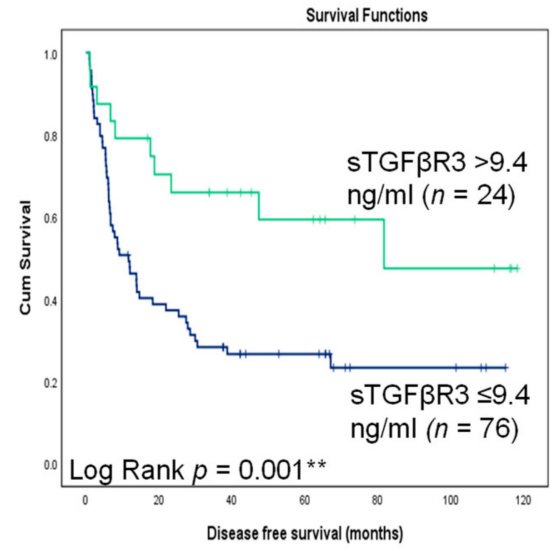

F)

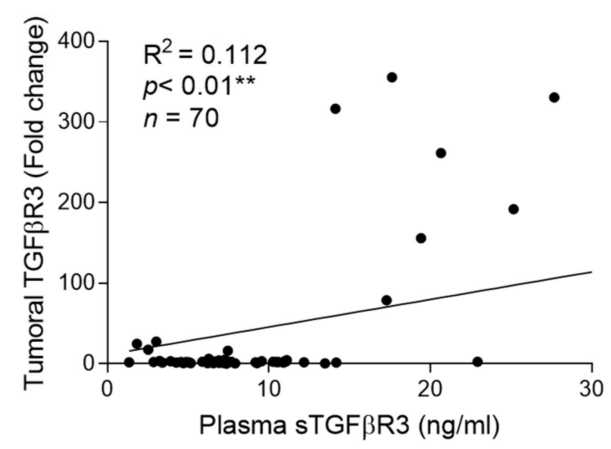

Figure 2. Clinical significances of sTGF $\beta$ R3 down-regulation in HCC plasma. (A) ELISA analysis of plasma sTGF $\beta$ R3 in patients. (B) Receiver operation characteristics (ROC) curve analysis. The clinical values were accessed by differentiation of 100 preoperative HCC patients from 100 healthy individuals. The AUC was $0.838 \pm 0.032(p<0.01)$. (C,D) KaplanMeier analysis of overall survival and disease-free survival in HCC patients associated with the plasma level of sTGF $\beta$ R3. (E) Level of sTGF $\beta R 3$ in patients with different tumor stage. (F) Correlation between tumoral TGF $\beta$ R3 and plasma sTGFßR3. ${ }^{*} p<0.05,{ }^{* *} p<0.01$. Error bar indicated SEM. (Unpaired $t$-test for Figure 2A, E) (Chi-square test for Figure 2F) (Log rank test for Figure 2C,D).

\subsection{TGF $\beta$ R3 Treatment Suppressed HCC Tumor Growth In Vivo}

With the evidence of advanced tumor stage patients having poorly expressed TGF $\beta$ R3, its tumor-suppressive function was further studied in a nude mouse orthotopic liver cancer model. Weekly intraperitoneal injection of recombinant sTGF $\beta$ R3 ( $25 \mu \mathrm{g}$ per mouse) significantly reduced tumor density by bioluminescence, with a 2-fold decrease compared to the untreated group (276.9U \pm 40.65 vs. $138.1 \mathrm{U} \pm 29.1, p=0.017)$ (Figure 3A-i). Consistently, the HCC tumor volume measured after scarification was also found to be 1.6-fold lower in the sTGF $\beta R 3$ treatment group $\left(0.96 \mathrm{~cm}^{3} \pm 0.14 \mathrm{vs} .1 .53 \mathrm{~cm}^{3} \pm 0.2\right)(p=0.037)$ (Figure 3A-ii). Further TUNEL assay demonstrated the increase in apoptotic tumor cells in the sTGF $\beta$ R3 treatment group (Figure 3A-iii). 
A-i)
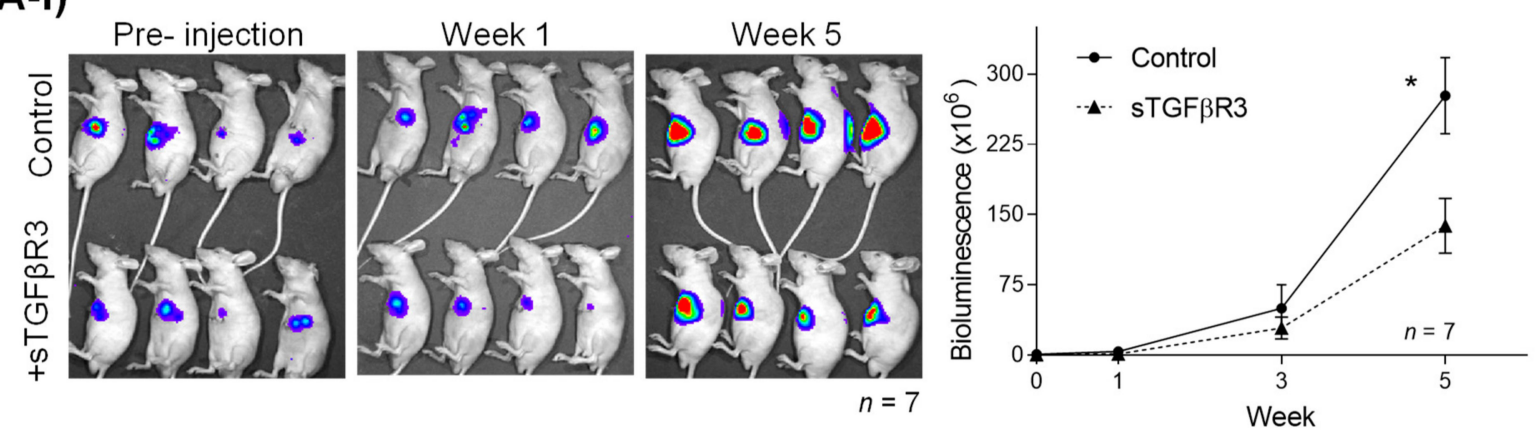

A-ii)
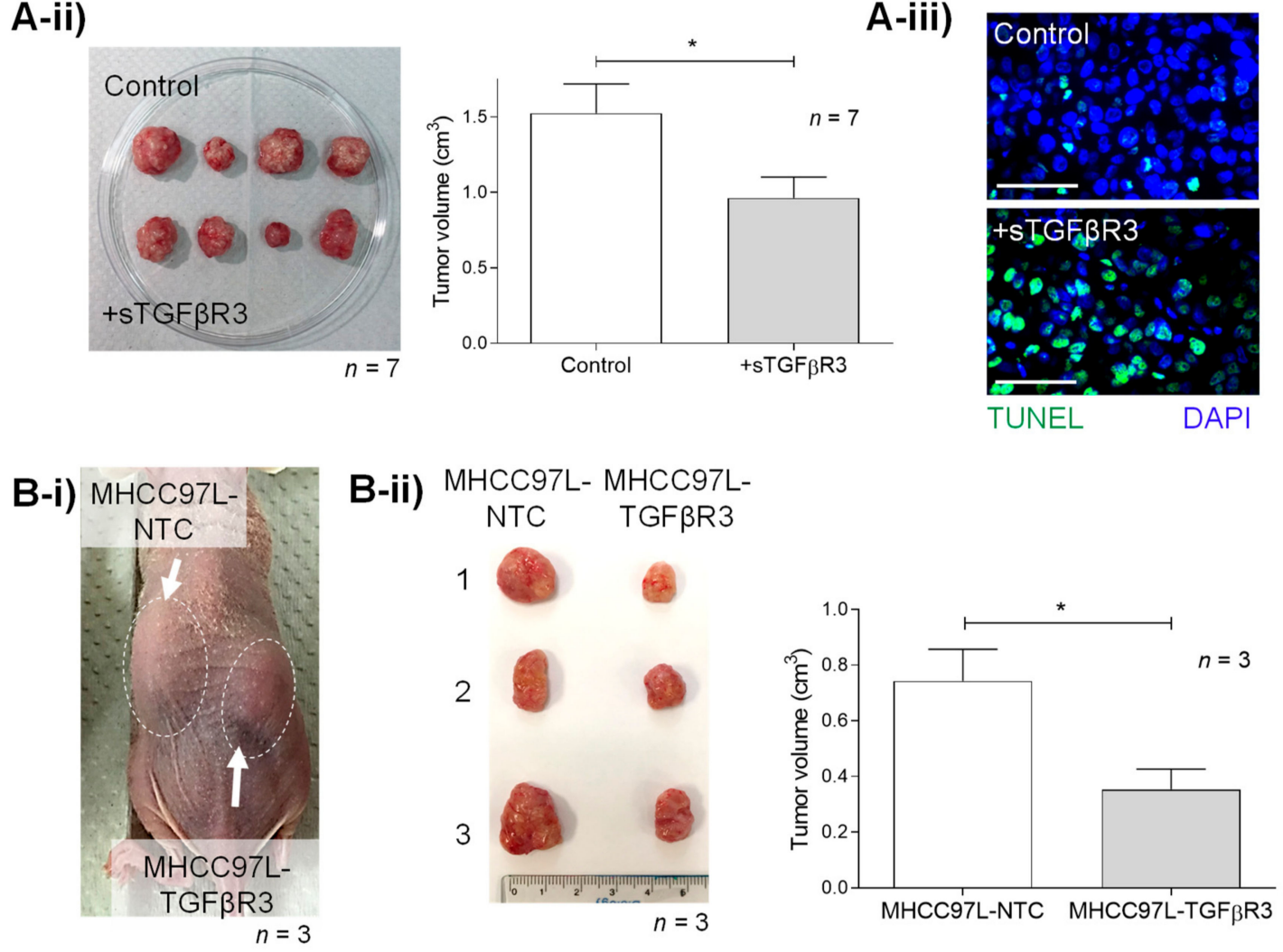

Figure 3. In vivo study of tumor-suppressive roles of (A) sTGF $\beta R 3$ and (B) TGF $\beta$ R3. (A) Male athymic mice bearing orthotopically grafted MHCC97L-Luciferase tumoral were injected with PBS (negative control) and $25 \mu \mathrm{g}$ sTGF 3 R3 ( $n=7$ ) peritoneally weekly. (A-i) Monitoring of in situ tumor growth by Xenogen IVIS before and 1-5 week after injection with measurements of mean in vivo liver tumor bioluminescence of each group over time. Bioluminescent signals were quantified as photons/s at each imaging timepoint. (A-ii) Following euthanasia, tumor volume was examined and measured in each mouse. (A-iii) TUNEL staining of liver tumor tissues in the treatment and control group. (B-i) Subcutaneous tumor model setup of tumor nodule induced by MHCC97L-NTC (control) on the left flank and MHCC97L-TGF $\beta$ R3 (knock-in) on the right flank in each mouse $(n=3)$. (B-ii) Tumor volume was examined and measured after scarification in week 4 . ${ }^{*} p<0.05$. Scale bar: $100 \mu \mathrm{m}$. Error bar indicated SEM. (Unpaired $t$-test).

Apart from sTGF $\beta$ R3, the tumor-suppressive role of TGF $\beta$ R3 was examined in a subcutaneous tumor model in nude mice, induced by the HCC cell-line MHCC97L, which was over-expressed with TGF $\beta$ R3 (MHCC97L-TGF $\beta R 3$ ). Including MHCC97L-NTC as a negative control, both the non-transfected and transfected cell-lines were injected into the left and right flank of each mouse, respectively (Figure 3B-i). A significant decrease in tumor size in the MHCC97L+TGF $\beta$ R3 $\left(0.35 \mathrm{~cm}^{3} \pm 0.07\right)$ group compared to MHCC97L-NTC $\left(0.74 \mathrm{~cm}^{3} \pm 0.11\right)$ was observed $(p=0.045)$ (Figure 3B-ii). 


\subsection{Loss of TGF $\beta$ R3 Induced the up-Regulation of C5a which Associated with Poor Prognosis} in HCC

To simulate its loss during HCC progression, TGF $\beta$ R3 was knocked out by transfection of a Crispr/Cas9 KO plasmid in two hepatic non-HCC cell lines MIHA and LO2. Through analysis by ELISA and molecular array study, we discovered a significant increase in complement component C5a secretion in both MIHA-TGF $\beta$ R3 KO $(0.833 \mathrm{ng} / \mathrm{mL} \pm 0.083)$ and LO2TGF $\beta R 3 \mathrm{KO}(0.66 \mathrm{ng} / \mathrm{mL} \pm 0.037)$ supernatants compared to vector control, parental MIHAscramble $(0.348 \mathrm{ng} / \mathrm{mL} \pm 0.061)$ and LO2-scramble cells $(0.23 \mathrm{ng} / \mathrm{mL} \pm 0.03)(p<0.01)$ (Figure 4A). Furthermore, high secretory levels of C5a in all HCC were identified (Figure 4B) with minimal co-expression with TGF $\beta$ R3 (Figure S3) in contrast to MIHA and LO2. Interestingly, we detected human $\mathrm{C} 5 \mathrm{a}$ in both tumoral tissue and plasma in an orthotopic nude mice model with MHCC97L-induced HCC tumor at week 4 (Figures S4 and S5). These demonstrated the capacity of continuous secretion of C5a by implanted lowTGFßR3-expression MHCC97L cells in vivo. Clinically, C5a-expressing HCC cells were also identified to be present in tumoral tissue (Figure S6). Quantitative analysis revealed the significant increase in the complement protein in patients' tumoral tissue (Figure 4C-i) and plasma (Figure $4 \mathrm{C}$-ii). Importantly, strong reverse relationships between $\mathrm{C} 5 \mathrm{a}$ and TGF $\beta R 3$ in both human liver tumor tissue $(p=0.0259)$ (Figure 4D-i) and plasma $(p=0.011)$ (Figure $4 \mathrm{D}$-ii) were validated. Consistent with the clinical phenotypes of TGF $\beta$ R3 downregulation, increased levels of plasma $\mathrm{C} 5 \mathrm{a}$ were first detected in patients with advanced (stage III, $13.4 \mathrm{ng} / \mathrm{mL} \pm 1.86$ and IV, $13.8 \mathrm{ng} / \mathrm{mL} \pm 3.003$ ) compared to early (stage I/II, $7.428 \mathrm{ng} / \mathrm{mL} \pm 1.075)$ tumor stage $(p=0.046)$ (Figure 4E). High levels of both tissue and plasma C5a were also observed to be strongly correlated with large tumor size $(p<0.01$; $p<0.0198)$ (Figure $4 \mathrm{~F}-\mathrm{i}, \mathrm{ii})$. Patients with high levels of plasma C5a $(>12 \mathrm{ng} / \mathrm{mL})$ developed significantly shorter disease-free survival compared to the low-expression group (Log rank: $5.798, p=0.016$ ) (Figure 4F-iii).

\subsection{Complement C5a Activated the Th-17 Responses in Tumor Promoting Macrophages}

In myeloid cells, macrophage is a major target of $\mathrm{C} 5 \mathrm{a}$, and as we had previously reported its critical roles in HCC, the function of the complement protein in the immune subset was further investigated. First, a positive correlation between plasma C5a and alternatively activated tumor (M2) macrophage marker (scavenger receptor) was identified in HCC patients $\left(\mathrm{R}^{2}=0.05, p=0.030\right)$ (Figure 5A). When analyzed by human PCR array, incubation of $1 \mu \mathrm{g} / \mathrm{mL}$ recombinant $\mathrm{C} 5 \mathrm{a}$ significantly induced the Th-17-related cytokines (IL-17, IL-21 and IL-22) and IL-17 regulatory genes (CXCL-1, CXCL-2, CSF-2) in M2 macrophages, but did not classically activate the M1 subtype (Figure 5B)(Supplementary Table S2). Significantly increased levels of C5a receptor were also detected in both activated macrophage populations in response to the complementary component (Figure S7). Importantly, incubating M2 macrophages with HCC-cell-cultured medium (MHCC97L, MHCC97H, Hep3B, PLC and Huh7) containing high levels of C5a significantly elevated the expression level of IL-17 (Figure 5C). Furthermore, patients with high levels of plasma C5a exhibited up-regulation of IL-17-secreting macrophages in HCC tumor in both immunostaining (Figure 5C) and flow cytometry analysis (Figure 5D). 
A)

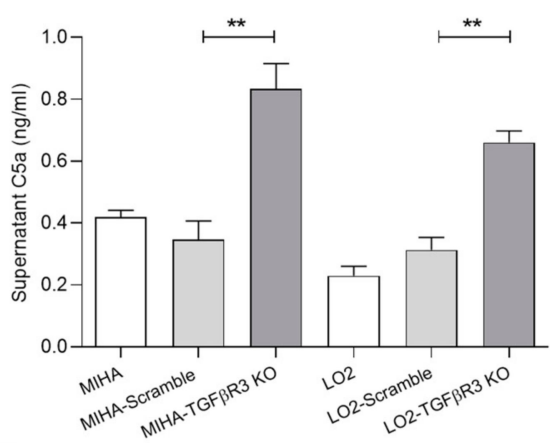

C-i)

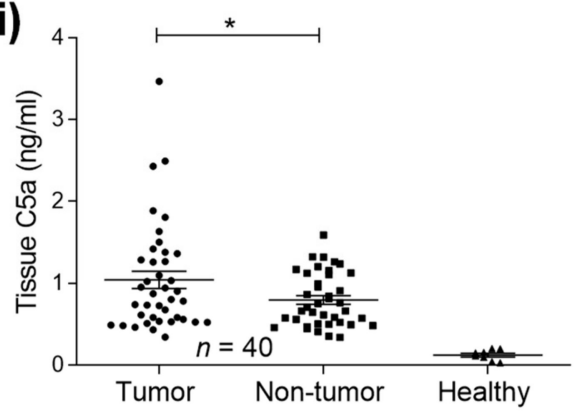

D-i)

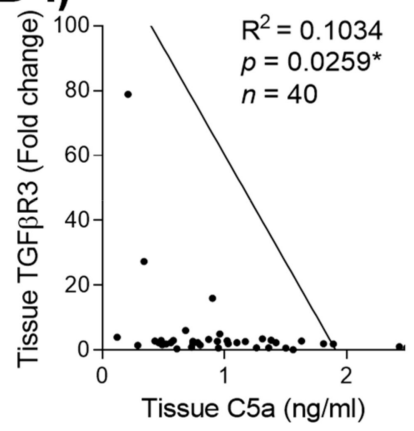

F-i)

D-ii)

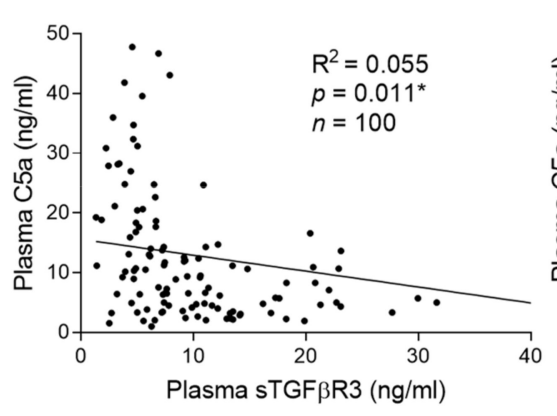

F-ii)

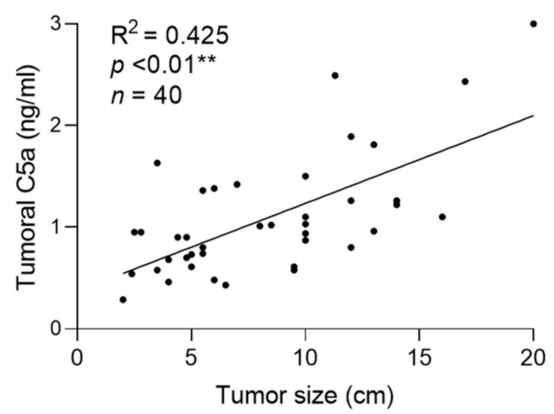

B)

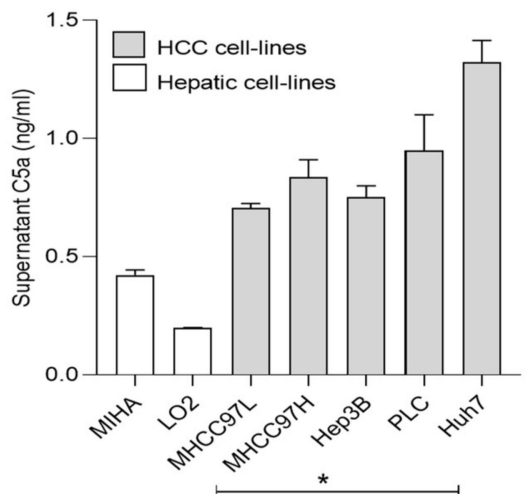

C-ii)

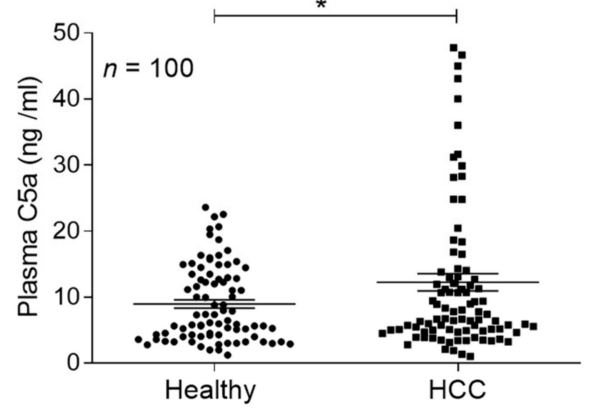

E)

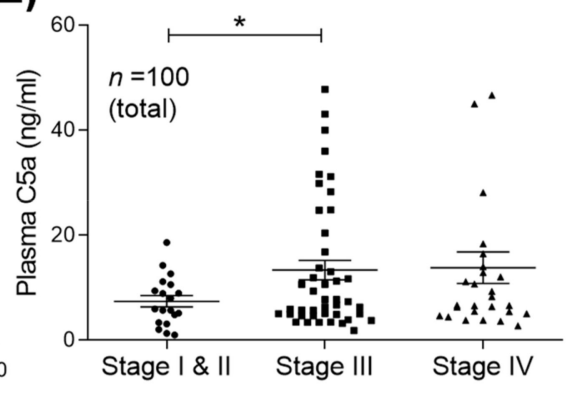

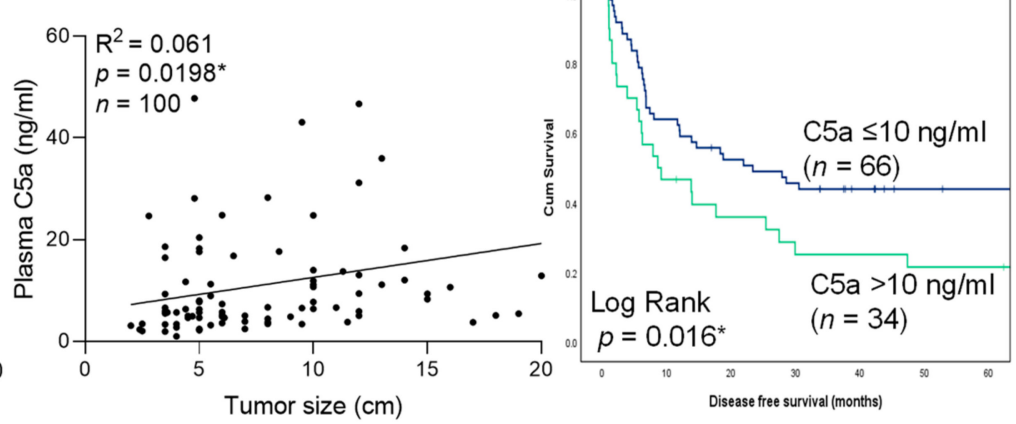

Figure 4. Loss of TGF $\beta$ R3 induced the upregulation of C5a in HCC. (A) TGF $\beta$ R3 transcript analysis of two non-HCC hepatocyte cell lines, MIHA and LO2, knock-out by CRISPR/Cas9 (MIHA-TGFßR3 KO) and (LO2-TGFßR3 KO). Level of secretory $\mathrm{C} 5 \mathrm{a}$ in (B) hepatocyte and HCC cell lines. (C-i) Tumoral, adjacent non-tumoral and healthy liver tissue, (C-ii) healthy and HCC patients' plasma. (D-i) Correlation analysis of tissue TGFßR3 and C5a. (D-ii) Correlation analysis of plasma C5a and sTGFßR3. (E) Level of plasma C5a HCC patients with different tumor stages. Correlation analysis of tumor size with the level of (F-i) tumoral and (F-ii) plasma C5a. (F-iii) Kaplan-Meier analysis of disease-free survival in HCC patients associated with plasma C5a. ${ }^{*} p<0.05,{ }^{* *} p<0.01$. Error bar indicated SEM. (Unpaired $t$-test for Figure 4A,B,C,E) (Chi-square test for Figure 4D,Fi-ii)(Log rank test for Figure 4Fiii). 

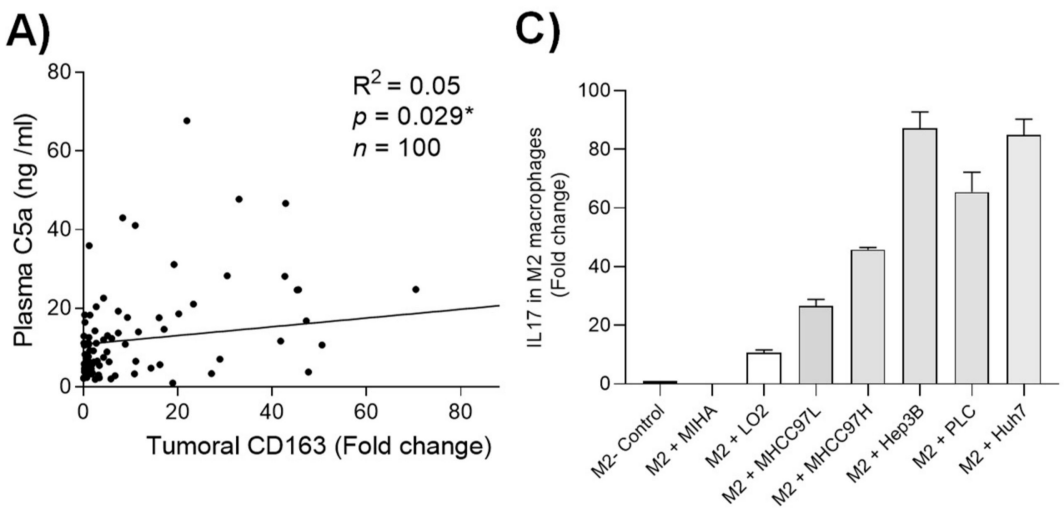

D)

B)

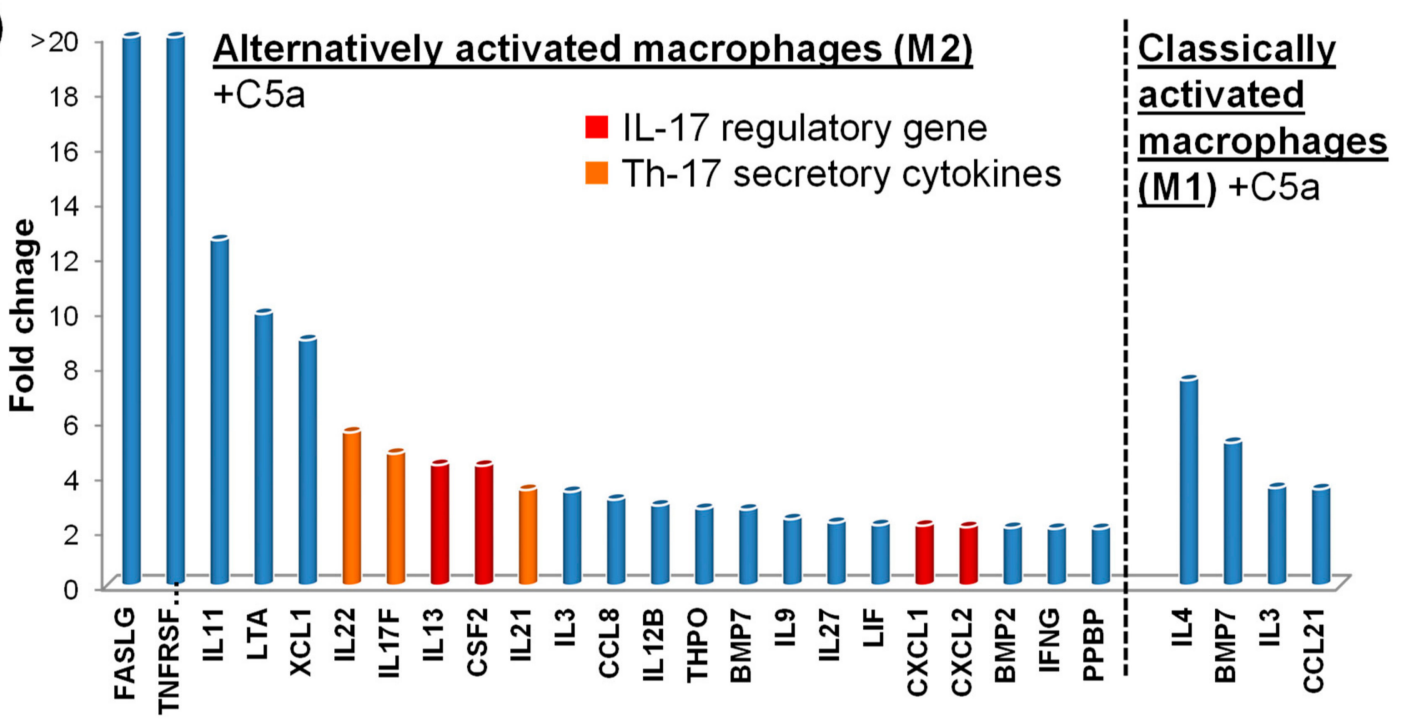

E)
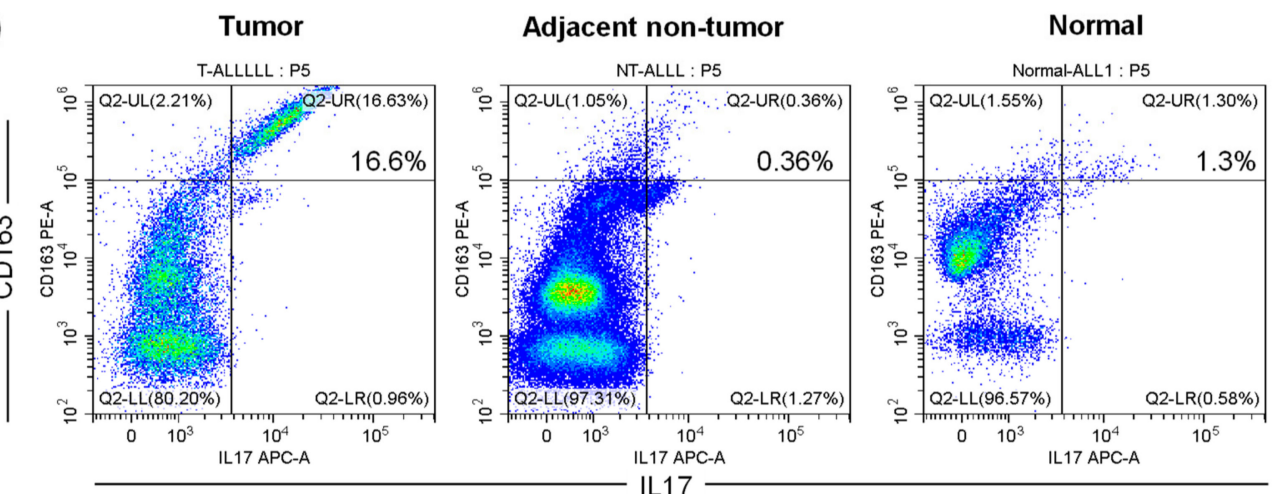

Figure 5. The protumor functions of C5a via M2 macrophages activation. (A) Correlation between plasma C5a and scavenger receptor (SA) expression level in the tumoral tissues. (B) cDNA expression array analysis of M1 and M2 macrophages treated with recombinant C5a compared to untreated group. (C) Expression of IL-17 in M2 macrophages after incubation of HCC-conditioned medium. (D) Double immunofluorescence image of a clinical tumoral section labeled with antibodies against IL-17 (green) and CD163 (red). (E) Expression of surface CD163 and intra-cellular IL-17 in total CD45+ population of tumoral, adjacent non-tumoral tissue and healthy liver tissue isolated from HCC patients measured by flow cytometry. Scale bar: $100 \mu \mathrm{m}$. Error bar indicated SEM. (Chi-square test for Figure 5A)(Unpaired $t$-test for Figure 5C).

\section{Discussion}

Despite the predominant downregulation of TGF $\beta$ R3 shown in both public databases and other studies [9], the clinical implication in HCC is unknown to date. For the first time, we revealed that decreased levels of tumoral and plasma TGF $\beta$ R3 are strongly associated with advanced tumor stage and tumor size, and, more importantly, poor clinical 
outcome, including shortened overall and disease-free survival. Apart from its prognostic associations, high differential levels of soluble TGF $\beta$ R3 in plasma between HCC patients and healthy individuals indicated the diagnostic potential, as validated by ROC curve analysis with the highly specific cut-off value of $9.4 \mathrm{ng} / \mathrm{mL}$. All the evidence collectively highlighted the clinical significance of TGF $\beta$ R3 downregulation in HCC patients.

Based on the clinical evidence, the tumor-suppressive function of TGF $\beta$ R3 in HCC was speculated and revealed in two tumor models. First, the continuous administration of recombinant sTGF $\beta$ R3 significantly decreased HCC tumor size by 2 -fold compared to controls in the orthotopic nude mice liver tumor model, with an increased level of tumor cell apoptosis. Similar antitumor activity of recombinant sTGF $\beta$ R3 in tumor models was previously reported in breast and prostate cancer $[4,6,10,11]$, indicating its effectiveness against different malignancies but not in HCC. Apart from STGF $\beta$ R3, restoring TGF $\beta$ R3 in lowly expressed HCC cells also significantly reduced tumor growth by 2.1-fold in the subcutaneous tumor model. Findings from both models collectively illustrated the direct tumor-suppressive functions of TGF $\beta$ R3 in HCC. Several studies indicate that TGF $\beta$ R3 suppresses tumor development via negatively mediating TGF- $\beta$ signaling [12-14]. In the present study, we identified the significant up-regulation of phospho-SMAD2/3 in tumoral tissue with minimal expression levels of TGF $\beta$ R3 (Figure S8).

The mechanisms of TGF $\beta$ R3 dysregulation remain unknown and it is tempting to correlate them with tumor hypoxia based on the close relationship between hypoxia-inducing factor 1 alpha (HIF- $1 \alpha$ ) and the TGF- $\beta$ signaling pathway. Nevertheless, emerging evidence has shown that loss of TGF $\beta$ R3 is related to paracrine or cell autonomous signaling, resulting in the alteration in the tumor immune environment, including dendritic cells [6]. Apart from cellular mechanism, recent studies reported that the disruption of TGF $\beta$ R3 induced the dysregulation of the complement components, including C4a and the complement factor $\mathrm{D}$ in breast and prostate cancer $[5,15]$. Since the liver possesses many unique immunological properties, as the residence of many immunological cells and the synthesis site of numerous innate proteins, including complement components, we speculated an induced tumor-promoting immunological mechanism following the dysregulation of TGF $\beta$ R3 in HCC. More importantly, we previously reported that alternatively activated (M2) macrophages represented the key immune population contributing to HCC progression [8]. Hence, we focused on studying the secretory profiles of TGF $\beta$ R3-down-regulated cells to identify potential immune-regulatory mechanisms associated with macrophages in HCC. By silencing TGF $\beta$ R3 in normal hepatocytes, we observed elevated secretion of one particular complement component, $\mathrm{C} 5 \mathrm{a}$, but not $\mathrm{C} 3 \mathrm{a}$ and $\mathrm{C} 4 \mathrm{a}$. Further studies confirmed that HCC cell-lines with low TGF $\beta$ R3 expression also displayed high secretory level of C5a.

Apart from being the central chemo-attractant provoking an innate immune response, emerging evidence has also suggested the novel roles of $\mathrm{C} 5 \mathrm{a}$ in shaping the tumor immune microenvironment $[16,17]$. Most tumors are rich in complement proteins, particularly C3a and $\mathrm{C} 5 \mathrm{a}$, produced directly by cancer cells, which have a variety of tumor-promoting mechanisms without activating the complement cascade [18-22]. Clinically, the concentration of both plasma and tumoral $\mathrm{C} 5 \mathrm{a}$ determine the disease progression in malignancies, including the lung and ovaries $[18,23,24]$. Noteworthy hepatocytes are responsible for biosynthesizing the majority of complement proteins. Despite the close relationship between hepatocyte and C5a, its clinical implications and underlying mechanisms in HCC are currently unclear. For the first time, we showed that HCC cells upregulated the secretion of C5a, which is particularly induced by the downregulation of TGF $\beta$ R3. High levels of the complement protein were associated with late tumor stage, increased tumor size and poor disease-free survival in HCC patients, consistent with the clinical associations of decreased TGF $\beta$ R3 expression. On the other hand, both the tumoral and circulatory levels of C5a were found to be highly dependent on both tumoral and soluble TGF $\beta$ R 3 in reverse manners. The clinical and in vitro evidence collectively suggested that dysregulation of TGF $\beta$ R3 in hepatocyte and HCC cells activated the secretion of pro-tumoral C5a in HCC. 
C5a possess many immuno-modulatory functions, particularly in the innate immunity $[17,19]$. Direct cytokine and chemokine production in the immune cells are also found to be regulated by the complement protein [25]. Here, we discovered the novel role of C5a in enhancing the tumor-promoting phenotypes on the alternatively activated (M2) macrophage. The treatment of either HCC cells supernatants with rich-in-C5a or recombinant $\mathrm{C} 5 \mathrm{a}$ to $\mathrm{M} 2$ macrophages significantly induced its expression of $\mathrm{C} 5 \mathrm{aR}$ and, surprisingly, IL-17 regulatory genes (CXCL-1, CXCL-2, MCSF, IL-17F) and Th-17 secretory cytokines (IL-17F, IL-21 and IL-22). In contrast, a minimal effect of C5a in another subtype, classically activated (M1) macrophage, was observed. Numerous studies suggested the clinical significance of Th-17 responses in contributing to poor survival outcome in HCC patients by the pro-tumor functions of IL-17, IL-21 and IL-22, including tumor proliferation and angiogenesis [26-30]. Importantly, the capability of HCC-stroma-associated macrophages in inducing Th-17 $\mathrm{T}$ cell response was shown [31]. The findings in the present study collectively indicated a novel mechanism of $\mathrm{C} 5 \mathrm{a}$ in activating Th-17 tumor-promoting phenotypes in M2 macrophages.

In conclusion, we first reported that both the downregulation of TGF $\beta R 3$ and increased C5a are associated with poor clinical outcomes in HCC. Plasma sTGF $\beta$ R3 served as a potential diagnostic biomarker for identifying patients with advanced tumor stages. A novel pro-tumoral mechanism of TGF $\beta$ R3 downregulation via C5a-activated tumorpromoting macrophages was revealed. Further applications of sTGF $\beta R 3$ and the C5a inhibitor may represent a new approach to treating HCC patients.

\section{Materials and Methods}

\subsection{Patient Samples}

Liver tumor tissues and blood samples were randomly collected from 100 patients (aged 3-83 years, 77\% male) who underwent curative surgery for HCC in Queen Mary Hospital from 2004 to 2008. Normal liver tissues were from a healthy living donor $(n=100)$. Ethical approval (UW11-100 (HKU/HA HKW IRB)) was obtained from the University of Hong Kong and Hospital Authority-Hong Kong Western Cluster and consent was signed by the studied patients.

\subsection{Orthotopic Nude Mice Liver Tumor Model with sTGFBR3 Treatment}

Male athymic nude mice (BALB/c nu/nu, 4-6 weeks old) (total number $=20)$ were used and all the studies were conducted according to the Animals (Control of Experiments) Ordinance (Hong Kong) and the Institute's guidance on animal experimentation. All mice were housed in a pathogen-free animal facility at $22 \pm 2{ }^{\circ} \mathrm{C}$ under controlled $12-\mathrm{h}$ light/dark cycles. Mice were given regular chow (5053-PicoLab ${ }^{\circledR}$ Rodent Diet 20, Lab Diet, $\mathrm{MO}$, USA) and had access to autoclaved water. Surgical procedures were as described previously [32]. Briefly, $3 \times 10^{5}$ MHCC97L suspended in $0.2 \mathrm{~mL}$ DMEM were injected subcutaneously into the flanks of mice. After 4 weeks, the subcutaneous tumors were resected and diced into $1 \mathrm{~mm}^{3}$ cubes, which were then implanted in the left lobes of the livers of another group of nude mice. Simultaneously, $2 \mathrm{mg} / \mathrm{kg}$ of recombinant sTGF $\beta$ R3 were injected peritoneally in the treatment group weekly for four weeks. For the number of mice applied for the experiment, seven were used for both the treatment groups and as a negative control. Mice injected with PBS served as a negative control. Tumor size and metastasis of MHCC97L xenograft were monitored weekly by Xenogen IVIS ${ }^{\circledR}$ (Xenogen IVIS $^{\circledR}$ 100, Caliper Life Sciences, Hopkinton, MA, USA). All mice were sacrificed at week 5 and the size of liver tumor was measured.

\subsection{RT2 Profiler PCR Array}

Total RNA was extracted from C5a treated $(1 \mu \mathrm{g} / \mathrm{mL}, 12 \mathrm{~h})$ and untreated M1 and M2 macrophages, using the TRIzol reagent (Invitrogen) and purified with the RNAeasy MinElute Cleanup Kit (Qiagen) according to standard protocols and converted to first strand cDNA using RT2 First Strand Kit (Qiagen). Gene expression of 84 cytokines and 
chemokines-related genes was analyzed using the Human Cytokines and Chemokines RT2 Profiler ${ }^{\mathrm{TM}}$ PCR Array (PAHS-150Z, Qiagen) according to the manufacturer's protocol.

\subsection{In Vitro Over-Expression and Knockout of TGF $\beta R 3$}

TGF $\beta$ R3-deficient non-HCC hepatocytes LO2 and MIHA were established using a CRISPR/Cas9 system with the plasmid TGF $\beta R 3$ CRISPR/Cas9 KO Plasmid (SC-401316) purchased from Santa Cruz Biotech. Control CRISPR/Cas9 Plasmid (SC-418922) was applied as a negative control. All the cells were transfected using Lipofectamine 2000 (Life Technologies) for $48 \mathrm{~h}$ with $3 \mu \mathrm{g}$ TGF $\beta \mathrm{R} 3$ and control plasmid. The transfection efficiency was determined by fluorescent microscopy and cells were sorted by FACS analysis. On the other hand, to over-express TGF $\beta$ R3 in HCC MHCC97L cell line, a TGF $\beta$ R3 human clone, the pCMV6-AC-GFP vector, was purchased from Origene Technologies.

\subsection{In Vivo Study of Tumorigenicity of TGF $\beta$ R3 Over-Expressed Cells}

Male athymic nude mice (BALB/c nu/nu, 4-6 weeks old) were used. For the xenograft tumor growth assay, control cells (MHCC97L-NTC) were injected subcutaneously into the left dorsal flank of mice, and TGF $\beta$ R3-expressing cells (MHCC97L-TGF $\beta R 3$ ) were injected into the right dorsal flank of the same animal. Tumor formation in nude mice was monitored over a 4-week period, and the tumor volume was measured weekly and calculated as $0.5 \times \mathrm{L} \times \mathrm{W} 2$. The mice were euthanized on the fifth week, and the tumors were excised and embedded in paraffin. Sections $(5 \mu \mathrm{m})$ of tumors were stained with H\&E to visualize the tumor structure.

\subsection{Quantitative Real Time RT-PCR}

Total RNA was extracted from cell lines and frozen tumor specimens using Trizol Reagent (Invitrogen). Total RNA was reverse-transcribed with High-Capacity cDNA Reverse Transcription Kit (Applied Biosystems). Messenger RNA expression levels were determined by real-time PCR using Fast Start SYBR Green Master (Roche Diagnostic) with an ABI Prism 770 sequence detection system. Primers used for the amplification of human genes were as follows.

Transforming growth factor beta type III receptor (TGF $\beta$ R3) forward: 5'-ACC GTG ATG GGC ATT GCG TTT GCA-3' , reverse: $5^{\prime}$-GTG CTC TGC GTG CTG CCG ATG CTG T-3'. C5aR forward: 5'-GAG CCC AGG AGA CCA GAA CAT G-3', reverse: 5'-TAC ATG TTG AGC AGG ATG AGG GA-3'. Class A macrophage scavenger receptor (SA) forward: 5'-GCA GGG CCC TCT TAA GAT CA $-3^{\prime}$, reverse: $5^{\prime}$-AAC ACG GGA ACC AAA GTC AT-3'. Interleukin 17 (IL-17) forward: 5'-TCC CAC GAA ATC CAG GAT GC-3', reverse: 5'-GGA TGT TCA GGT TGA CCA TCA C-3'. 18s forward: 5'-CTC TTA GCT GAG TGT CCC GC- $3^{\prime}$, reverse: $5^{\prime}-$ CTG ATC GTC TTC GAA CCT CC- $3^{\prime}$. For clinical tissue samples, the relative fold change of the target gene expressed in intratumor and peritumor tissue was determined by the following equation: $2-\Delta \Delta \mathrm{Ct}(\Delta \mathrm{Ct}=\Delta \mathrm{Cttarget}-\Delta \mathrm{Ct} 18 \mathrm{~s}$; $\Delta \Delta \mathrm{Ct}=\Delta \mathrm{Ct}-\Delta \mathrm{Ctnormal}$ ) which was normalized to the average fold change in the normal liver tissues defined as 1.0. TGF $\beta$ R3 expression level in each case was classified as either a high or low group determined by the ROC curve. For in vitro study, all experiments were performed in triplicate and repeated three times.

\subsection{Immunostaining and Flow Cytometry}

Immunohistochemistry and flow cytometry were applied to examine the level of different proteins (TGF 3 R3, CD163, C5a, IL-17 and glypican) in clinical specimens. For immuostaining, paraffin-embedded liver and liver tumor were sectioned to $4 \mu \mathrm{m}$ thickness. Endogenous peroxidase blockage and visualization were achieved with Dako Envision+ System (Dako). Following heat-induced epitope retrieval according to the manufacturer's protocol, incubation with antibodies against human TGF $\beta$ R3 (1:100, Abcam), CD163 (1:100, Leica Novocastra), C5a (1:200, Abcam), IL-17 (1:100, R\&D Systems) and glypican (1:100, Abcam) were performed. All immunohistochemistry and immunofluorescence images 
were taken by the Niken ELIPSE E600 and Invitrogen EVOS FL Color Imaging System, respectively. All flow cytometry analyses were performed by CytoFlex S Beckman Coulter.

\subsection{ELISA}

The level of soluble TGF $\beta$ R3 (Sigma) and complement component C5a (BD Biosciences) were quantified in patients' plasma and tumoral tissue. All procedures were performed according to the manufacturer's instructions.

\subsection{Cell Culture and Stimulation}

Authentication for the MHCC97L, MIHA and LO2 cells used in the present study was performed using Powerplex 16 HS kit (Promega) after PCR amplification and capillary electrophoresis. The human acute monocytic leukemia cell line THP-1 was purchased from ATCC and maintained according to ATCC guidelines. Other hepatic and HCC cell-lines were purchased or obtained as described in the Supplementary CTAT Table. The protocols of M1 and M2 macrophage polarization from THP-1 were adopted from Tjiu et al. [33]. Briefly, to induce M1-polarized phenotype, $25 \mathrm{ng} / \mathrm{mL}$ interferon gamma (IFN- $\gamma$; Invitrogen) and $150 \mathrm{ng} / \mathrm{mL}$ lipopolysaccharide (LPS; Sigma) were added to $1 \times 10^{\mu} \mathrm{THP}-1$. To induce M2-polarized phenotype, $20 \mathrm{ng} / \mathrm{mL}$ of recombinant interleukin 4 (IL-4; Invitrogen) and recombinant interleukin 13 (IL-13; R\&D Systems) were used. All stimulation lasted $24 \mathrm{~h}$ at $37^{\circ} \mathrm{C}$, and culture was washed thoroughly with PBS three times prior to further study.

For luciferase-labeling, MHCC97L were transfected with luciferase gene in pGL3 vector (Promega), and positive clones were selected according to luciferase activity in Xenogen In Vivo Imaging System 100 (Xenogen IVIS ${ }^{\circledR}$ 100, Xenogen Corporation).

\subsection{Statistical Methods}

Comparisons and correlations of quantitative data between the two groups were analyzed by unpaired Student's $t$-test and chi-square test, respectively. Categorical data were analyzed by Fisher's exact test. The Cox proportional hazards model was applied to determine the independent factors of survival, based on the variables selected on univariate analysis. The log-rank test for comparison of survival in Kaplan-Meier survival plot was used for analysis. A $p<0.05$ was considered statistically significant. All analyses were performed with Graphpad Prism 5.0 and SPSS18.0.

\section{Conclusions}

In conclusion, we first reported that both the downregulation of TGF $\beta$ R 3 and increased C5a were associated with poor clinical outcome in HCC. Plasma sTGF $\beta$ R3 could serve as a novel diagnostic biomarker for identifying patients with advanced tumor stages. A novel pro-tumoral mechanism of TGF $\beta$ R3 downregulation via C5a-activated tumor-promoting macrophages was revealed. Therapeutic potentials involving the applications of sTGF $\beta$ R3 and C5a inhibitor may represent a new approach to treating HCC patients.

Supplementary Materials: The following are available online at https:/ /www.mdpi.com/2072-669 4/13/7/1503/s1. Figure S1: Downregulation of TGF $\beta$ R3 expression in HCC tumor from publicly available datasets. Figure S2: Kaplan-Meier analysis of overall survival and disease-free survival in HCC patients associated with the expression level of tumoral TGF $\beta$ R3 transcript from publicly available database GEPIA. Figure S3: Flow cytometry analysis of TGF $\beta$ R3 and intracellular C5a expression in HCC cell-lines. Figure S4: Presence of human C5a in tumoral tissue of a mouse HCC orthotopic model. Figure S5: Presence of human C5a in plasma of a mouse HCC orthotopic model. Figure S6: The secretion of C5a in glypican 3 expressed HCC cells. Figure S7: Increased expression of $\mathrm{C} 5 \mathrm{a}$ receptor $(\mathrm{C} 5 \mathrm{aR})$ in macrophage sub-populations treated with recombinant $\mathrm{C} 5 \mathrm{a}$. Figure S8: Increased $p$-SMAD 2/3 expression in HCC tumoral tissue. Table S1: Clinical characteristics of the studied population. Table S2: Transcript analysis of C5a treated M1 and M2 macrophages. 
Author Contributions: Conceptualization, O.W.H.Y.; data curation, O.W.H.Y. and X.Q.; formal analysis, O.W.H.Y., X.Q., L.P. and H.L.; funding acquisition, K.M., O.W.H.Y. and C.M.L.; methodology, O.W.H.Y., X.Q., K.T.P.N. and J.L.; project administration, K.M., K.T.P.N. and C.M.L.; resources, K.M., H.L. and C.M.L.; software, X.Q. and J.L.; writing-original draft, O.W.H.Y.; writing-review and editing, K.M., L.P. and C.M.L. All authors have read and agreed to the published version of the manuscript.

Funding: Grant support: 1. Young Scientist Fund (81902520) from National Natural Science Foundation of China to Yeung; 2. Health and Medical Research Fund (HMRF) (05161816) from the Food and Health Bureau, Hong Kong to Yeung; 3. Theme-based Research Scheme (TBRS) (T12-703/19R) from the University Grants Committee, Hong Kong to Lo and Man.

Institutional Review Board Statement: The study was conducted according to the guidelines of the Declaration of Helsinki, and approved by the Institutional Review Board of The University of Hong Kong (UW11-100 (HKU/HA HKW IRB)) and the Animals (Control of Experiments) Ordinance (Hong Kong).

Informed Consent Statement: Informed consent was obtained from all subjects involved in the study.

Data Availability Statement: The data presented in this study are available on request from the corresponding author.

Conflicts of Interest: The authors declare no conflict of interest.

\section{References}

1. Giannelli, G.; Villa, E.; Lahn, M. Transforming Growth Factor- $\beta$ as a Therapeutic Target in Hepatocellular Carcinoma. Cancer Res. 2014, 74, 1890-1894. [CrossRef] [PubMed]

2. Bilandzic, M.; Stenvers, K.L. Betaglycan: A multifunctional accessory. Mol. Cell. Endocrinol. 2011, 339, 180-189. [CrossRef]

3. Gatza, C.E.; Oh, S.Y.; Blobe, G.C. Roles for the type III TGF- $\beta$ receptor in human cancer. Cell. Signal. 2010, 22, 1163-1174. [CrossRef]

4. Bandyopadhyay, A.; López-Casillas, F.; Malik, S.N.; Montiel, J.L.; Mendoza, V.; Yang, J.; Sun, L.-Z. Antitumor Activity of a Recombinant Soluble Betaglycan in Human Breast Cancer Xenograft. Cancer Res. 2002, 62, 4690-4695. [PubMed]

5. Jovanović, B.; Pickup, M.W.; Chytil, A.; Gorska, A.E.; Johnson, K.N.; Moses, H.L.; Owens, P.H. TßRIII Expression in Human Breast Cancer Stroma and the Role of Soluble T $\beta$ RIII in Breast Cancer Associated Fibroblasts. Cancers 2016, 8, 100. [CrossRef]

6. Hanks, B.A.; Holtzhausen, A.; Evans, K.S.; Jamieson, R.; Gimpel, P.; Campbell, O.M.; Hector-Greene, M.; Sun, L.; Tewari, A.; George, A.; et al. Type III TGF- $\beta$ receptor downregulation generates an immunotolerant tumor microenvironment. J. Clin. Investig. 2013, 123, 3925-3940. [CrossRef]

7. European Association For The Study Of The Liver. EASL-EORTC clinical practice guidelines: Management of hepatocellular carcinoma. J. Hepatol. 2012, 56, 908-943. [CrossRef]

8. Yeung, O.W.; Lo, C.M.; Ling, C.-C.; Qi, X.; Geng, W.; Li, C.-X.; Chang-Chun, L.; Forbes, S.J.; Guan, X.Y.; Poon, R.T.; et al. Alternatively activated (M2) macrophages promote tumour growth and invasiveness in hepatocellular carcinoma. J. Hepatol. 2015, 62, 607-616. [CrossRef]

9. Chen, J.; Gingold, J.A.; Su, X. Immunomodulatory TGF- $\beta$ Signaling in Hepatocellular Carcinoma. Trends Mol. Med. 2019, 25, 1010-1023. [CrossRef] [PubMed]

10. Bandyopadhyay, A.; Wang, L.; López-Casillas, F.; Mendoza, V.; Yeh, I.-T.; Sun, L.-Z. Systemic administration of a soluble betaglycan suppresses tumor growth, angiogenesis, and matrix metalloproteinase- 9 expression in a human xenograft model of prostate cancer. Prostate 2004, 63, 81-90. [CrossRef] [PubMed]

11. Elderbroom, J.L.; Huang, J.J.; Gatza, C.E.; Chen, J.; How, T.; Starr, M.; Nixon, A.B.; Blobe, G.C. Ectodomain shedding of T $\beta$ RIII is required for T $\beta$ RIII-mediated suppression of TGF- $\beta$ signaling and breast cancer migration and invasion. Mol. Biol. Cell 2014, 25, 2320-2332. [CrossRef] [PubMed]

12. Chu, W.; Li, X.; Li, C.; Wan, L.; Shi, H.; Song, X.; Liu, X.; Chen, X.; Zhang, C.; Shan, H.; et al. TGFBR3, a potential negative regulator of TGF- $\beta$ signaling, protects cardiac fibroblasts from hypoxia-induced apoptosis. J. Cell. Physiol. 2011, 226, 2586-2594. [CrossRef] [PubMed]

13. Yin, Z.; Ma, T.; Huang, B.; Lin, L.; Zhou, Y.; Yan, J.; Zou, Y.; Chen, S. Macrophage-derived exosomal microRNA-501-3p promotes progression of pancreatic ductal adenocarcinoma through the TGFBR3-mediated TGF- $\beta$ signaling pathway. J. Exp. Clin. Cancer Res. 2019, 38, 1-20. [CrossRef]

14. Dong, M.; How, T.; Kirkbride, K.C.; Gordon, K.J.; Lee, J.D.; Hempel, N.; Kelly, P.; Moeller, B.J.; Marks, J.R.; Blobe, G.C. The type III TGF- $\beta$ receptor suppresses breast cancer progression. J. Clin. Investig. 2007, 117, 206-217. [CrossRef] [PubMed]

15. Sharifi, N.; Hurt, E.M.; Kawasaki, B.T.; Farrar, W.L. TGFBR3 loss and consequences in prostate cancer. Prostate 2007, 67, 301-311. [CrossRef] 
16. Ajona, D.; Ortiz-Espinosa, S.; Pio, R. Complement anaphylatoxins C3a and C5a: Emerging roles in cancer progression and treatment. Semin. Cell Dev. Biol. 2019, 85, 153-163. [CrossRef]

17. Roumenina, L.T.; Daugan, M.V.; Petitprez, F.; Sautès-Fridman, C.; Fridman, W.H. Context-dependent roles of complement in cancer. Nat. Rev. Cancer 2019, 19, 698-715. [CrossRef] [PubMed]

18. Corrales, L.; Ajona, D.; Rafail, S.; Lasarte, J.J.; Riezu-Boj, J.I.; Lambris, J.D.; Rouzaut, A.; Pajares, M.J.; Montuenga, L.M.; Pio, R. Anaphylatoxin C5a Creates a Favorable Microenvironment for Lung Cancer Progression. J. Immunol. 2012, 189, 4674-4683. [CrossRef]

19. Markiewski, M.M.; DeAngelis, R.A.; Benencia, F.; Ricklin-Lichtsteiner, S.K.; Koutoulaki, A.; Gerard, C.; Coukos, G.; Lambris, J.D. Modulation of the antitumor immune response by complement. Nat. Immunol. 2008, 9, 1225-1235. [CrossRef]

20. Nitta, H.; Murakami, Y.; Wada, Y.; Eto, M.; Baba, H.; Imamura, T. Cancer cells release anaphylatoxin C5a from C5 by serine protease to enhance invasiveness. Oncol. Rep. 2014, 32, 1715-1719. [CrossRef]

21. Piao, C.; Cai, L.; Qiu, S.; Jia, L.; Song, W.; Du, J. Complement 5a Enhances Hepatic Metastases of Colon Cancer via Monocyte Chemoattractant Protein-1-mediated Inflammatory Cell Infiltration. J. Biol. Chem. 2015, 290, 10667-10676. [CrossRef] [PubMed]

22. Afshar-Kharghan, V. The role of the complement system in cancer. J. Clin. Investig. 2017, 127, 780-789. [CrossRef] [PubMed]

23. Gunn, L.; Ding, C.; Liu, M.; Ma, Y.; Qi, C.; Cai, Y.; Hu, X.; Aggarwal, D.; Zhang, H.-G.; Yan, J. Opposing roles for complement component C5a in tumor progression and the tumor microenvironment. J. Immunol. 2012, 189, 2985-2994. [CrossRef] [PubMed]

24. Bjørge, L.; Hakulinen, J.; Vintermyr, O.K.; Jarva, H.; Jensen, T.S.; Iversen, O.E.; Meri, S. Ascitic complement system in ovarian cancer. Br. J. Cancer 2005, 92, 895-905. [CrossRef] [PubMed]

25. Grailer, J.J.; Bosmann, M.; Ward, P.A. Regulatory effects of C5a on IL-17A, IL-17F, and IL-23. Front. Immunol. 2013, 3, 387. [CrossRef] [PubMed]

26. Zhang, J.-P.; Yan, J.; Xu, J.; Pang, X.-H.; Chen, M.-S.; Li, L.; Wu, C.-Y.; Li, S.; Zheng, L. Increased intratumoral IL-17-producing cells correlate with poor survival in hepatocellular carcinoma patients. J. Hepatol. 2009, 50, 980-989. [CrossRef]

27. Radaeva, S.; Sun, R.; Pan, H.-N.; Hong, F.; Gao, B. Interleukin 22 (IL-22) plays a protective role in T cell-mediated murine hepatitis: IL-22 is a survival factor for hepatocytes via STAT3 activation. Hepatology 2004, 39, 1332-1342. [CrossRef] [PubMed]

28. Langowski, J.L.; Kastelein, R.A.; Oft, M. Swords into plowshares: IL-23 repurposes tumor immune surveillance. Trends Immunol. 2007, 28, 207-212. [CrossRef] [PubMed]

29. Langowski, J.L.; Zhang, X.; Wu, L.; Mattson, J.D.; Chen, T.; Smith, K.; Basham, B.; McClanahan, T.; Kastelein, R.A.; Oft, M. IL-23 promotes tumour incidence and growth. Nature 2006, 442, 461-465. [CrossRef] [PubMed]

30. Numasaki, M.; Fukushi, J.-I.; Ono, M.; Narula, S.K.; Zavodny, P.J.; Kudo, T.; Robbins, P.D.; Tahara, H.; Lotze, M.T. Interleukin-17 promotes angiogenesis and tumor growth. Blood 2002, 101, 2620-2627. [CrossRef]

31. Hammerich, L.; Heymann, F.; Tacke, F. Role of IL-17 and Th17 Cells in Liver Diseases. Clin. Dev. Immunol. 2010, $2011,1-12$. [CrossRef] [PubMed]

32. Ng, K.T.-P.; Man, K.; Sun, C.K.; Lee, T.K.W.; Poon, R.T.; Lo, C.-M.; Fan, S.-T. Clinicopathological significance of homeoprotein Six1 in hepatocellular carcinoma. Br. J. Cancer 2006, 95, 1050-1055. [CrossRef] [PubMed]

33. Tjiu, J.-W.; Chen, J.-S.; Shun, C.-T.; Lin, S.-J.; Liao, Y.-H.; Chu, C.-Y.; Tsai, T.-F.; Chiu, H.-C.; Dai, Y.-S.; Inoue, H.; et al. TumorAssociated Macrophage-Induced Invasion and Angiogenesis of Human Basal Cell Carcinoma Cells by Cyclooxygenase-2 Induction. J. Investig. Dermatol. 2009, 129, 1016-1025. [CrossRef] 